\title{
KANDUNGAN KIMIA DAN DIMENSI SERAT AKAR, CABANG DAN BATANG BAGIAN ATAS KAYU GMELINA DAN KAYU JATI DI HUTAN RAKYAT SULAWESI SELATAN
}

\author{
Chemical Content and Fiber Dimension of Root, Branch and Upper Stem of Gmelina and Jati Wood at \\ Community Forest, South Sulawesi \\ Syahidah, Hikmah dan A. Detti Yunianti
}

\begin{abstract}
The wood species used in this research was gmelina wood from community forest, Maros Regency and jati wood from community forest, Barru Regency. For objective of the research, parts of the tree were taken a short cut $(5 \mathrm{~cm})$ from root, branch and top of the tree. All samples were tested their chemical component (cellulose, hemicellulose, lignin and extractives) and fiber dimensions with it's derivates fiber. The results showed that root, branch and top of the tree of gmelina wood and jati wood from community forest can be used as a raw material for pulp and papers.
\end{abstract}

Key words: Chemical content, Fiber Dimension, Gmelina Wood, Jati Wood, Community Forest

\section{PENDAHULUAN}

Penanaman di hutan rakyat ditujukan untuk pemenuhan kebutuhan kayu bagi masyarakat di sekitar hutan dan sebagai sumber pendapatan tambahan. Pemanfaatan tanaman di hutan rakyat sampai saat ini masih belum jelas, hanya menunggu pembeli yang menawarkan harga tinggi sehingga tujuan penanaman hanya berorientasi kuantitas tanpa memperhatikan kualitas kayu yang akan dihasilkan dan tujuan penggunaannya.

Upaya pemanfaatan yang optimal perlu dilakukan untuk meningkat nilai jual dari tegakan yang ada di hutan rakyat, salah satunya adalah memanfaatkan bagian dari pohon yang tidak diperdagangkan atau limbah kayu yang selama ini diabaikan pemanfaatannya. Di dalam penebangan suatu pohon, bagian pohon seperti batang bagian atas, cabang dan akar sampai saat ini masih merupakan limbah kayu dan penggunaannya belum optimal bahkan cenderung dijadikan kayu bakar.

Mengetahui kandungan kimia dan dimensi serat dari limbah kayu dapat meningkatkan penggunaan kayu bukan hanya sebagai kayu bakar tetapi dapat dijadikan bahan baku pulp dan kertas, dengan melihat kualitas seratnya. Berdasarkan uraian di atas dilakukan penelitian kandungan kimia dan dimensi serat limbah kayu di hutan rakyat yang akan menjadi acuan untuk pemanfaatan lebih lanjut dari limbah kayu guna meningkatkan nilai dari tegakan di hutan rakyat.

\section{BAHAN DAN METODE}

Bahan yang digunakan pada penelitian ini adalah kayu gmelina yang berasal dari Hutan Rakyat Purnakarya Kec. Tanralili Kab. Maros dan kayu jati yang berasal Hutan Rakyat Desa Balusu, Kec. Balusu, Kab. Barru. Bagian pohon yang dijadikan sampel penelitian adalah batang bagian atas, cabang dan akar. Bagian batang atas yang berdiameter $<10 \mathrm{~cm}$, bagian cabang dan akar masing-masing pada diameter terbesar. Dari masing-masing bagian diambil lempengan tipis ( 5 $\mathrm{cm}$ ) kemudian dibuat contoh uji untuk analisis kimia sampel kayu dibuat serbuk sedangkan untuk pengujian dimensi serat dibuat berupa batangan korek api.

Analisis komponen kimia mengacu pada standar TAPPI (Technical Association for Pulp and Paper Industry) meliputi kandungan sellulose, hemisellulose, lignin dan kelarutan ekstraktif dalam alkohol benzena. Pengukuran dimensi serat terhadap individu serat yang terlebih dahulu dipisahkan melalui proses maserasi. Pengukuran dimensi serat yaitu panjang serat, diameter lumen, diameter serat dan tebal dinding serat dengan bantuan mikroskop perbesaran $40 \mathrm{x}$ dan $10 \mathrm{x}$. Dari hasil pengukuran dimensi serat dihitung nilai turunan dimensi serat yaitu runkel ratio, felting 
power, flexibility ratio, coefficient of rigidity dan muhlsteph ratio untuk mengetahui kualitas serat.

\section{HASIL DAN PEMBAHASAN}

\section{Komponen Kimia Kayu}

Nilai komponen kimia kayu dari akar, cabang dan batang atas kayu gmelina dan kayu jati yang berasal dari Hutan Rakyat Sulawesi Selatan disajikan pada Tabel 1.

Kandungan sellulosa pada Tabel $1 \mathrm{di}$ atas jika dibandingkan dengan klasifikasi komponen kimia kayu daun lebar Indonesia, maka cabang dan batang atas mempunyai kandungan sellulosa yang tinggi sedangkan bagian akar mempunyai kandungan sellulosa sedang pada masing-masing kayu gmelina dan kayu jati. Persyaratan untuk bahan baku pulp dan kertas yaitu kandungan sellulosa tinggi karena kandungan sellulosa yang tinggi akan menghasilkan rendemen pulp yang tinggi dan afinitas yang lebih besar terhadap air (Pari dan Lestari, 1990). Kandungan hemisellulosa termasuk rendah untuk ketiga bagian pohon pada masing-masing jenis kayu.
Kandungan lignin termasuk sedang pada masing-masing jenis kayu kecuali bagian akar kayu jati termasuk tinggi. Kandungan lignin yang tinggi akan menyebabkan konsumsi alkali tinggi (Casey, 1980) sehingga bagian yang terbaik untuk bahan baku pulp adalah bagian akar, cabang dan batang bagian atas pada kayu gmelina dan bagian batang atas dan cabang pada kayu jati.

Kelarutan ekstraktif dalam alkohol benzena termasuk rendah pada masing-masing jenis kayu kecuali bagian akar kayu jati termasuk sedang. Ekstraktif dapat menyebabkan bintik-bintik pada lembaran pulp yang dihasilkan (Pitch problem), sehingga bagian yang terbaik untuk bahan baku pulp adalah akar, cabang dan batang bagian atas pada kayu gmelina dan cabang dan batang bagian atas pada kayu jati yang mempunyai kandungan ekstraktif yang rendah.

\section{Dimensi Serat}

Hasil pengukuran dimensi serat bagian akar, cabang dan batang bagian atas kayu gmelina dan kayu jati yang berasal dari Hutan Rakyat Sulawesi Selatan dapat dilihat pada Tabel 2.

Table 1. The Chemical Components from Root, Branch and Upper Stem of Gmelina and Jati Wood at Community Forest in South of Sulawesi

\begin{tabular}{llccc}
\hline \multirow{2}{*}{ Species } & \multicolumn{1}{c}{ Chemical } & \multicolumn{3}{c}{ Part of Unmerchantable Tree ( \% ) } \\
\cline { 3 - 5 } Gmelina & Components & Root & Branch & Upper Stem \\
& Cellulose & 43.565 & 49.355 & 50.195 \\
& Hemicellulose & 19.333 & 20.495 & 18.675 \\
& Lignin & 27.350 & 20.690 & 20.420 \\
& Extractives & 1.195 & 1.030 & 1.145 \\
\hline Jati & Cellulose & 42.865 & 45.920 & 46.700 \\
& Hemicellulose & 14.600 & 15.605 & 14.265 \\
& Lignin & 34.065 & 28.590 & 30.070 \\
& Extractives & 2.155 & 1.920 & 1.885 \\
\hline
\end{tabular}

Table 2. Fiber Dimension from Root, Branch and Upper Stem of Gmelina and Jati Wood at Community Forest in South of Sulawesi

\begin{tabular}{|c|c|c|c|c|c|}
\hline \multirow[b]{2}{*}{ Species } & \multirow{2}{*}{$\begin{array}{c}\text { Part of Un- } \\
\text { merchantable } \\
\text { Tree }\end{array}$} & \multicolumn{4}{|c|}{ Fiber Dimension $(\mu)$} \\
\hline & & $\begin{array}{l}\text { Length of } \\
\text { Fiber }(L)\end{array}$ & $\begin{array}{c}\text { Fiber } \\
\text { Diameter (d) }\end{array}$ & $\begin{array}{c}\text { Lumen } \\
\text { Diameter (I) }\end{array}$ & $\begin{array}{c}\text { Cell Wall } \\
\text { Thickness (w) }\end{array}$ \\
\hline \multirow[t]{3}{*}{ Gmelina } & Root & 1170 & 21.75 & 12.50 & 4.63 \\
\hline & Branch & 1005 & 25.25 & 18.50 & 3.38 \\
\hline & Upper Stem & 1028 & 25.50 & 16.75 & 4.38 \\
\hline \multirow[t]{3}{*}{ Jati } & Root & 1402 & 23.50 & 14.75 & 4.38 \\
\hline & Branch & 1323 & 19.00 & 11.00 & 4.00 \\
\hline & Upper Stem & 1250 & 22.50 & 25.00 & 3.75 \\
\hline
\end{tabular}


Table 3. Derivates of Fiber from Root, Branch and Upper Stem of Gmelina and Jati Wood

\begin{tabular}{ccccc}
\hline \multirow{2}{*}{ Species } & \multirow{2}{*}{ Derivates Fiber } & \multicolumn{3}{c}{ Part of Unmerchantable Tree } \\
\cline { 3 - 5 } Gmelina & Root & Branch & Upper Stem \\
& Runkel Ratio & 0.74 & 0.36 & 0.52 \\
& Felting Power & 53.79 & 39.80 & 40.31 \\
& Flexibility Ratio & 0.57 & 0.73 & 0.66 \\
& Coeff of Rigidity & 0.21 & 0.13 & 0.17 \\
& Muhl.Ratio (\%) & 0.67 & 0.46 & 0.57 \\
\hline \multirow{3}{*}{ Jati } & Runkel Ratio & 0.59 & 0.73 & 0.3 \\
& Felting Power & 59.66 & 69.63 & 55.55 \\
& Flexibility Ratio & 0.63 & 0.58 & 1.11 \\
& Coeff of Rigidity & 0.19 & 0.21 & 0.17 \\
& Muhl.Ratio (\%) & 0.61 & 0.66 & 0.23 \\
\hline
\end{tabular}

Peranan dimensi serat seperti panjang, diameter dan tebal dinding serat mempunyai hubungan satu sama lain yang kompleks dan mempunyai pengaruh terhadap tujuan penggunaannya. Kriteria penetapan kemungkinan sebagai bahan baku pulp dan kertas dapat dikaji melalui nilai panjang serat dan nilai turunan dimensi serat dan penentuan kelas kualitas serat (Vademecum Kehutanan, 1976). Tabel 3 menunjukkan nilai turunan serat dari bagian akar, cabang dan batang bagian atas kayu gmelina dan kayu jati dari Hutan Rakyat Sulawesi Selatan

Runkel ratio adalah ratio antara dua kali tebal dinding serat dengan diameter lumen. Dari nilai runkel ratio cabang kayu gmelina $(0,36)$ termasuk kualitas pulp kelas II, sedangkan batang atas $(0,52)$ dan akar $(0,74)$ termasuk kualitas pulp kelas III. Runkel ratio batang atas kayu jati $(0,3)$ termasuk kualitas pulp kelas II, sedangkan akar $(0,59)$ dan cabang $(0,73)$ termasuk kualitas pulp kelas III. Nilai runkel ratio yang semakin kecil, semakin baik sebagai bahan baku pulp karena mempunyai dinding serat yang tipis. Serat yang tipis apabila dibuat kertas akan menghasilkan lembaran yang lebih pipih dan hasil ikatan serat yang diperoleh lebih kuat dan baik.

Felting power cabang $(39,80)$ dan batang atas $(40,31)$ kayu gmelina termasuk kualitas pulp kelas III sedangkan akar $(53,79)$ kayu gmelina termasuk kualitas pulp kelas II. Sementara felting power cabang $(69,63)$, akar $(59,66)$ dan batang atas $(55,55)$ kayu jati termasuk kualitas pulp kelas II. Felting power yang makin besar umumnya makin tinggi kekuatan sobek dari kertas tersebut. Dalam hal ini panjang serat merupakan faktor yang paling penting dalam menjalin ikatan serat, makin panjang serat makin meningkatkan kekuatan sobek kertas.
Flexibility ratio adalah perbandingan antara diameter lumen dengan dimeter serat. Kualitas pulp cabang $(0,73 ; 0,58)$ dan akar $(0,57 ; 0,63)$ kayu gmelina dan jati serta batang atas kayu gmelina $(0,66)$ termasuk kelas II, sedangkan batang atas kayu jati $(1,11)$ termasuk kualitas pulp kelas I. Flexiibility ratio yang tinggi menghasilkan lembaran pulp dengan kekuatan yang baik karena makin tinggi flexisibility ratio berarti serat makin tipis sehingga ikatan antar serat yang terjadi makin baik. Hasil penelitian ini menunjukkan batang atas kayu jati lebih baik dari bagian lainnya.

Coefficient of rigidity merupakan perbandingan antara tebal dinding serat dengan diameter serat. Nilai coefficient of rigidity dari akar $(0,21)$ dan batang atas $(0,17)$ kayu gmelina serta akar $(0,19)$, cabang $(0,21)$ dan batang atas $(0,17)$ kayu jati termasuk kualitas pulp kelas III sementara cabang $(0,13)$ kayu gmelina termasuk kualitas pulp kelas II. Coefficient of rigidity berbanding terbalik dengan felting power maupun flexibility ratio. Makin rendah coefficient of rigidity, kertas yang dihasilkan makin tidak mudah putus apabila terkena beban tarik. Hasil penelitian ini memperlihatkan cabang kayu gmelina yang terbaik karena coeffisient of rigidity-nya terendah.

\section{KESIMPULAN DAN SARAN}

Bagian akar, cabang dan batang bagian atas kayu gmelina dan kayu jati yang berasal dari Hutan Rakyat Sulawesi Selatan bila ditinjau dari panjang serat dan nilai turunan serat umumnya memiliki kualitas seart kelas II dengan komponen kimia yang cukup baik untuk menjadi bahan baku pulp dan kertas. Penelitian tentang penggunaan lebih lanjut sebagai produk papan serat perlu dilakukan 
untuk meningkatkan nilai tegakan kayu gmelina dan kayu jati di Hutan Rakyat Sulawesi Selatan

\section{UCAPAN TERIMA KASIH}

Kami berterima kasih kepada Koordinator Kopertis Wilayah IX Sulawesi yang telah membiayai penelitian ini melalui Proyek Anggaran Rutin Kopertis Wilayah IX Sulawesi.

\section{DAFTAR PUSTAKA}

Anonimous, 1976. Vademekum Kehutanan Indonesia. Departemen Pertanian. Dirjen Kehutanan. Jakarta.

Casey, J.P. 1980. Pulp, Paper Chemistry and Chemical Technology. Third edition. Vol 1. Willey Interscience Publisher inc. New York.

Pari, G dan S.B. Lestari. 1990. Analisa Kimia Beberapa Jenis Kayu Indonesia. Jurnal Penelitian Hasil Hutan. Vol.7. No. 3. Bogor.

Tappi, 1989. Tappi Test Methods. Volume One. Tappi, Atlanta

Diterima : 12 November 2006

Syahidah dan A. Detti Yunianti

Lab. Sifat Dasar dan Teknologi Kimia Hasil Hutan

Jurusan Kehutanan, Universitas Hasanuddin

Kampus Tamalanrea, Jl. Perintis Kemerdekaan Km. 10, Makassar 90245

Telp./Fax. 0411-585917. Indonesia

\section{Hikmah}

Jurusan Kehutanan, Univ. Satria Makassar

Jl. Veteran, Makassar 